\title{
Physical-Chemical Properties of Poultry Rendering Meal of Whole Broiler Carcasses Stored for Different Times and Temperatures
}

\author{
Débora A. Alves ${ }^{1}$, Everton L. Krabbe ${ }^{2}$, Valdir S. de Avila², Cristiéle L. Contreira1, Gizelle C. \\ Bedendo², Francisco N. Fonseca ${ }^{2}$, Diego Surek², Lana F. Baron ${ }^{3}$, Suelen N. da Silva ${ }^{1^{*}}$, \\ Juliana Forgiarini' ${ }^{1}$, Eduardo G. Xavier ${ }^{1}$ \\ Accepted 20 September 2020 \\ 1'Department of Animal Science, Eliseu Maciel Agronomy College, Federal University of Pelotas, Pelotas, Rio Grande \\ do Sul, 96010-610, Brazil \\ Embrapa Swine and Poultry, Brazilian Agricultural Research Corporation, Concórdia, Santa Catarina, 89700-000, \\ Brazil \\ ${ }^{3}$ Department of Pharmaceutical Sciences, College of Pharmacy, Federal University of Rio Grande do Sul, Porto \\ Alegre, Rio Grande do Sul, 90610-000, Brazil
}

\begin{abstract}
The effect of storage temperature on the physical-chemical properties of poultry rendering meals (PRM) of whole broiler carcasses was evaluated. Chemical parameters, oxidation and biogenic amines (BA) profiles were determined. A completely randomized design in a 2x4 factorial arrangement (two stored temperature: 26 ${ }^{\circ} \mathrm{C}$ or $7 \stackrel{\circ}{\circ} \mathrm{C}$; and four storage times: $0,24,48$ and $72 \mathrm{~h}$ before rendering) was used. PRM nutrient levels were within the acceptable ranges determined for animal byproducts in all treatments and they did not influence PRM acidity index or TBARS $(P>0.05)$. The peroxide index of all PRM was higher than the acceptable limit $(>10$ $\mathrm{meq} / \mathbf{1 0 0 0 \mathrm { g }}$ ) but did not cause a rancid odor. Lower total BA content was determined at $72 \mathrm{~h}$ of storage in PRMs from refrigerated carcasses. The nutrient composition of PRMs shows quality enough to possibly be utilized as a feedstuff. Additional studies are needed to establish the safety of these byproducts as feedstuffs.
\end{abstract}

Keywords: biogenic amines, byproduct, feedstuff, nutritional composition

${ }^{*}$ Corresponding author. Email: suelennunesdasilva@hotmail.com; Tel: +55 (53) 981022210.

\section{INTRODUCTION}

Brazil is currently the world's second-largest producer of chicken meat $(13,245$ thousand tons/year) and the world's largest exporter, with a total of 4,214 thousand tons/year (ABPA, 2020). One of the challenges of this huge production scale is the disposal of birds that die during the production cycle. Due to the lack of scientific knowledge and regulations on new technologies, those live production residues are not appropriately disposed of, posing human and animal health risks, as well as environmental contaminants.

Brazil processes around 5.6 billion broilers per year, and flocks have an average mortality of $3 \%$, which represents approximately 204,000 tons of carcasses/year (Krabbe and Wilbert, 2016). Poultry accounts for the secondlargest mortality volume in Brazilian animal production of dead animals, after beef cattle, with an average of 730,000 tons (Krabbe and Wilbert, 2016). Therefore, it is urgent to develop novel technologies for the disposal of birds that die during the production cycle and rendering of these carcasses have been studied as an alternative (Hamilton et al., 2006). A recent study showed that renderings related to the poultry industry achieved the best ratings overall, compared to other animal by-product meals (Leiva et al., 2018). However, this is controversial, as it is difficult to standardize the rendering of raw materials to be processed and to reach economical and food safety aspects as well as the origin of rendered carcasses (Bellaver, 2002; Leiva et al., 2018). The quality of rendered animal meals is typically established on physical-chemical parameters, oxidative profile 
(acidity and peroxide index), and microbial load to ensure the absence of pathogenic microorganisms, particularly Salmonella sp., Clostridium perfringens, and heatresistant spores (Jorge Neto, 1994; BRAZIL, 2003; Leiva et al., 2018). Animal products are rich in protein, containing amino acids susceptible to breakdown, that can result in biogenic amines (BA) (Stadnik and Dolatowski, 2010; Lázaro et al., 2015). These compounds have low molecular weight and are essentially products of the enzymatic decarboxylation of free amino acids and the transamination of aldehydes and ketones (Latorre-Moratalla et al., 2010; Cardozo et al., 2013). In addition, the microorganisms responsible for the fermentation process may contribute to the accumulation of BA in rendered animal meals. Moreover, inadequate processing and/or storage conditions increase BA levels in rendered animal meals, lowering their quality (Bover-Cid et al., 2006; Latorre-Moratalla et al., 2010).

The increasing animal production scale and intensification have generated significant challenges for the disposal of the carcasses of birds that die during the production cycle. Over the past three decades, the poultry sector has grown more than $5 \%$ a year, which is a significant growing, particularly in comparison to pork $(3 \%)$ and beef (1.5\%) (Gerber, 2007). Poultry companies have recently researched some possibilities, such as the refrigerated storage of dead birds and subsequent destination to rendering plants. In Brazil, a regulation of the Ministry of Agriculture (BRAZIL, 2008) establishes hygiene conditions and health parameters for rendering animal residues derived from processing plants and intended for animal consumption. Such regulation does not allow that animal mortality constitutes raw material for animal by-product meals. Consequently, it is considered unsuitable as a feedstuff.

However, despite the legal issues, this study aimed at evaluating the quality of poultry meals rendered from carcasses of dead birds stored at different temperatures up to $72 \mathrm{~h}$, and so supporting further discussions about the proper destination of such meals.

\section{MATERIAL AND METHODS}

\section{Birds}

The experimental protocol was approved by the Committee of Ethics on Experimental Animals (CEEA) of the Federal University of Pelotas, under protocol number $9084 / 2016$. Commercial Cobb 500 broilers $(n=224)$ were reared under standard management and feeding conditions until 46 days of age $(3.0 \mathrm{~kg}$ average body weight).

\section{Experimental design}

The experiment was carried out at the facilities of Embrapa Swine and Poultry Research Agency, located in Concordia City, state of Santa Catarina, Brazil. All birds were slaughtered and their carcasses were distributed according to a completely randomized design in a $2 \times 4$ factorial arrangement, consisting of two storage temperatures (refrigerated or room temperature) and four storage periods $(0,24,48$ and $72 \mathrm{~h})$, totaling eight treatments.

Thirty-two carcasses were rendered immediately after slaughter $(0 \mathrm{~h})$ and formed the control treatment. The remaining 192 carcasses were stored either under refrigeration $\left(7^{\circ} \mathrm{C}\right)$ in a cold storage room (96 carcasses) or at room temperature $\left(26{ }^{\circ} \mathrm{C}\right)$ in a closed room (96 carcasses) and rendered at 24, 48, and $72 \mathrm{~h}$ after storage. Therefore, each storage period $(24,48$ and 72 h) had eight replications of four carcasses each.

Breast $\mathrm{pH}$ was measured in the fresh carcasses $(\mathrm{Oh})$ and the carcasses stored at different temperatures and for different times using a portable $\mathrm{pH}$ meter $(\mathrm{HI}$ 9813-6, Hanna instruments).

\section{Rendering process}

Whole carcasses (with feathers and offal) from each treatment were ground with an industrial meat grinder (CAF - 10 inox) and homogenized manually. The cooking conditions simulated the industrial rendering of whole animal carcasses. At the beginning, $30 \%$ of soybean oil $(\mathrm{m}: \mathrm{m})$ were added to the digestor $(50-\mathrm{L}$ capacity) before cooking. Animal fat is typically added to the carcass mass in the rendering industry, but, in the current experiment, vegetable oil was used instead to avoid the possible presence of BA in the animal fat from previous raw material degradation. The raw carcass mass was placed in the digestor and cooked for $1 \mathrm{~h}$. During the first $30 \mathrm{~min}$, the mass was turned every $5 \mathrm{~min}$, after which the digestor was closed and the mass was cooked for further $30 \mathrm{~min}$ at $0.5 \mathrm{lb} / \mathrm{cm}^{2}$ and internal temperature $115{ }^{\circ} \mathrm{C}$. The resulting cooked mass was pressed (with a galvanized manual press for crackling) to separate the fat from the solid fraction, which was considered the poultry rendering meal (PRM). Then, eight replicates per treatment were pooled, placed in labeled plastic bags and stored in cold chamber at $-7^{\circ} \mathrm{C}$ for further analyses.

\section{Chemical analyses}

The chemical composition of the PRM of each treatment was determined according to the procedures of AOAC (1998). Fresh samples $(2 \mathrm{~g})$ were dried in a forcedventilation oven (Q317M, Quimis, Diadema, Brazil) at $105{ }^{\circ} \mathrm{C}$ for $18 \mathrm{~h}$ to determine dry matter (DM) content. Total ash content (Ash) was determined in fresh samples $(2 \mathrm{~g})$ in a forced-ventilation oven at $105^{\circ} \mathrm{C}$ for $18 \mathrm{~h}$, and then burnt in a muffle (Q318M, Quimis, Diadema, Brazil) at $550{ }^{\circ} \mathrm{C}$ for $3 \mathrm{~h}$.

In order to determine calcium $(\mathrm{Ca})$ and phosphorus $(\mathrm{P})$ contents, fresh samples $(0.5 \mathrm{~g})$ were digested with $6 \mathrm{~mL}$ 
of an $8: 1(\mathrm{v} / \mathrm{v}) \mathrm{HNO}_{3}-\mathrm{H}_{2} \mathrm{SO}_{4}$ solution for $30 \mathrm{~min}$ at $140{ }^{\circ} \mathrm{C}$ and heated to $180{ }^{\circ} \mathrm{C}$ until reaching $1-\mathrm{mL}$ final volume. This acid extract was diluted with ultrapure water to 25 $\mathrm{mL}$. Calcium content in the acid extract was determined with an atomic absorption spectrometer (Varian SpectrAA 220, Agilent Technologies, Santa Clara, CA), while $P$ content was determined with an UV-Vis spectrophotometer (Varian Cary 50 Probe, Agilent Technologies, Santa Clara, CA), according to the molibdovanadate reagent method.

Crude protein (CP) was calculated as total nitrogen content in the sample $\times 6.25$. Total nitrogen was obtained using the Kjeldahl method, in which a $0.2 \mathrm{~g}$ sample was digested with pure $\mathrm{H}_{2} \mathrm{SO}_{4}\left(400{ }^{\circ} \mathrm{C}, 45 \mathrm{~min}\right)$, distilled in alkaline medium, and titrated with $25 \mathrm{mM} \mathrm{H}_{2} \mathrm{SO}_{4}$ solution. Lipid content (ether extract) was determined by extracting the fat with petroleum ether under high pressure $\left(90{ }^{\circ} \mathrm{C}, 90 \mathrm{~min}\right)$ in an Ankom XT15 system (Ankom Technology, Macedon, NY).

\section{Oxidation profile}

Acidity index, thiobarbituric acid reactive substance (TBARS) content and peroxide index were measured to determine PRM oxidation profile as a function of storage temperature and time. The acidity index was measured according to the procedure described in the Brazilian Compendium of Animal Feeding (CBAA, 2004). Briefly, the sample $(5 \mathrm{~g})$ was mixed with absolute ethanol (150 $\mathrm{mL}$ ) and allowed to stand for $30 \mathrm{~min}$. The supernatant was filtered, and the residue was further extracted in 100 $\mathrm{mL}$ ethanol. The fractions were pooled, the volume adjusted to $250 \mathrm{~mL}$ and 5 drops of phenolphthalein were added. This mixture was titrated with $0.1 \mathrm{M} \mathrm{NaOH}$ until no color change was observed. The result was express in $\mathrm{mg} \mathrm{NaOH} / \mathrm{g}$.

Thiobarbituric acid reactive substance was determined by extracting samples $(0.2 \mathrm{~g})$ in 1-butanol $(25 \mathrm{~mL})$ according to the AOAC protocol (AOAC, 1998). A total of $5 \mathrm{~mL}$ of $0.2 \%$ 2-thiobarbituric acid (in 1-butanol) were added to $5 \mathrm{~mL}$ of the extract and the mixture was incubated at $95^{\circ} \mathrm{C}$ for $2 \mathrm{~h}$. The solution was allowed to $\mathrm{cool}$, and the absorbance was measured on a spectrophotometer (Varian Cary 50 Probe) at $532 \mathrm{~nm}$. In addition, increased concentrations (1-10 $\mu \mathrm{M})$ of TMP (1,1,3,3-tetramethoxypropane) were reacted as described for the sample and the absorbance read on a spectrophotometer (Varian Cary 50 Probe) to build a calibration curve for TBARS calculation. The result was expressed in $\mathrm{mg} \mathrm{NaOH} / \mathrm{g}$.

Peroxide index was obtained as described by Shantha and Decker (1995). Initially, a $\mathrm{Fe}^{2+}$ solution was prepared by dissolving $0.4 \mathrm{~g} \mathrm{BaCl}_{2} .2 \mathrm{H}_{2} \mathrm{O}$ in $50 \mathrm{~mL}$, followed by the addition of $0.5 \mathrm{~g} \mathrm{FeSO}_{4} .7 \mathrm{H}_{2} \mathrm{O}$ and $2 \mathrm{~mL}$ of $10 \mathrm{M} \mathrm{HCl}$. The solution was filtered to remove the precipitate $\left(\mathrm{BaSO}_{4}\right)$. The sample $(0.3 \mathrm{~g})$ was stirred in a tube with $9.8 \mathrm{~mL}$ of a chloroform:methanol solution $(7: 3, \mathrm{v} / \mathrm{v})$ and $50 \mu \mathrm{L}$ of ammonium thiocyanate solution $(0.3 \mathrm{~g} / \mathrm{mL})$, stirred, $50 \mu \mathrm{L}$ of the $\mathrm{Fe}^{2+}$ solution were added, and the solution was incubated at room temperature for 5 min protected from light. Absorbance was measured on a spectrophotometer (Varian Cary 50 Probe) at $500 \mathrm{~nm}$. The calibration curve was based from a serially-diluted standard $\mathrm{Fe}^{3+}$ solution $(1-40 \mu \mathrm{g} / \mathrm{mL})$, and reacted as described above. The result was expressed in $\mathrm{mg}$ $\mathrm{MDA} / \mathrm{g}$.

\section{Quantification of biogenic amines}

Biogenic amines were quantified by high-performance liquid chromatography (HPLC) using the method of Smělá et al. (2003) with modifications. Initially, 5-g samples were weighed and placed in falcon tubes, to which $10 \mu \mathrm{g} / \mathrm{mL}$ of the internal standard $(1,7-$ diaminoheptane) was added. After, $15 \mathrm{~mL}$ of $0.6 \mathrm{M}$ $\mathrm{HClO}_{4}$ was added and the solution was vortexed for 3 min. The sample was then centrifuged (IEC DPR-6000, Damon, Dunstable, England) for $30 \mathrm{~min}$ at $3500 \mathrm{rpm}$ and the supernatant collected and filtered $(0.45 \mu \mathrm{m})$ into a volumetric flask $(25 \mathrm{~mL})$.

The procedure was repeated with an additional $10 \mathrm{~mL}$ of $0.6 \mathrm{M} \mathrm{HClO}_{4}$ and the volume was adjusted to $25 \mathrm{~mL}$ with acid. In order to reduce sample fat content, acid extract was partitioned with hexane 1:2 (v/v), followed by centrifugation for $2 \mathrm{~min}$ at $5000 \mathrm{RPM}$. The acidic aqueous phase was collected and derivatized with dansyl chloride $(5 \mathrm{mg} / \mathrm{mL}$ in acetonitrile). Briefly, $0.5 \mathrm{~mL}$ of a solution containing $2 \mathrm{M} \mathrm{NaOH}$ and saturated $\mathrm{NaHCO}_{3}(2: 3, \mathrm{v} / \mathrm{v})$ were added to the sample $(1 \mathrm{~mL})$, followed by $2 \mathrm{~mL}$ of the derivatizing agent. The mixture was vortexed (1 $\mathrm{min}$ ) and the solution was left standing, protected from light, for $1 \mathrm{~h}$. Then $0.1 \mathrm{~mL}$ of pure $\mathrm{NH}_{4} \mathrm{OH}$ was added and the sample allowed to stand for further $30 \mathrm{~min}$. The liquid-liquid was extracted with ethyl ether ( 3 $x 0.5 \mathrm{~mL}$ ) and the ether fraction evaporated. Finally, the residue was solubilized in acetonitrile $(1 \mathrm{~mL})$, filtered $(0.22 \mu \mathrm{m})$ and analyzed in a HPLC chromatograph (Dionex Ultimate 3000 HPLC, Thermo Fischer Scientific, Waltham, MA).

Chromatographic separation was performed on reversephase column $(C 18,150 \times 4.6 \mathrm{~mm}, 5 \AA$, Thermo Fischer Scientific) using water and acetonitrile (ACN) as mobile phase, gradient elution (0-1 min: ACN 65\%/10 min: ACN 80\%/12 min: ACN 90\%/16 min: ACN 100\%/23 min: ACN $65 \% / 25 \mathrm{~min}: 65 \% \mathrm{ACN}$ ), with a flow rate of $0.8 \mathrm{~mL} / \mathrm{min}$ and $\lambda=254 \mathrm{~nm}$. Data were acquired and processed using the software Cromeleon ${ }^{\circledR} 6.0$ (Thermo Fischer Scientific). Calibration curves to quantify the biogenic amines were built based on a stock solution containing phenylethylamine, putrescine, cadaverine, histamine, tyramine, spermidine and spermine. The stock solution was serially diluted $(0.5-25 \mu \mathrm{g} / \mathrm{mL})$ in $0.1 \mathrm{M} \mathrm{HCl}$ and to the different dilutions added an internal standard (10 $\mu \mathrm{g} / \mathrm{mL}$ ). These standard solutions were derivatized as previously described and analyzed. Biogenic amine levels, expressed in $\mathrm{mg} / \mathrm{kg}$, were calculated by linear regression equations, which were considered adequate when $r>0.99$. 
Table 1. Chemical composition of poultry rendered meal from whole broiler carcasses stored at different temperatures and for different times.

\begin{tabular}{|c|c|c|c|c|c|c|c|c|}
\hline \multirow{2}{*}{ Parameter, \% } & \multirow{2}{*}{$\begin{array}{l}\text { Temp. } \\
{ }^{\circ} \mathrm{C}\end{array}$} & \multicolumn{4}{|l|}{ Time (h) } & \multicolumn{3}{|l|}{$P$ value } \\
\hline & & 0 (zero) & 24 & 48 & 72 & Time & Temp. & Time*Temp. \\
\hline \multirow{3}{*}{ Calcium } & 26 & $1.7 \pm 0.1$ & $1.9 \pm 0.5$ & $1.7 \pm 0.2$ & $2.0 \pm 0.3$ & & & \\
\hline & 7 & $1.7 \pm 0.1$ & $2.0 \pm 0.3$ & $1.9 \pm 0.4$ & $1.7 \pm 0.4$ & 0.1885 & 0.8857 & 0.1402 \\
\hline & 26 & $1.0 \pm 0.1$ & $1.1 \pm 0.2$ & $1.0 \pm 0.1$ & $1.1 \pm 0.2$ & & & \\
\hline \multirow[t]{2}{*}{ Phosphorus } & 7 & $1.0 \pm 0.1$ & $1.2 \pm 0.2$ & $1.2 \pm 0.2$ & $1.0 \pm 0.2$ & 0.2054 & 0.9271 & 0.2337 \\
\hline & 26 & $8.4 \pm 0.7$ & $8.4 \pm 0.9$ & $8.3 \pm 0.7$ & $9.1 \pm 0.9$ & & & \\
\hline \multirow[t]{2}{*}{ Ash } & 7 & $8.4 \pm 0.7$ & $9.3 \pm 1.5$ & $9.1 \pm 1.2$ & $8.4 \pm 1.2$ & 0.7211 & 0.3390 & 0.1384 \\
\hline & 26 & $18.5 \pm 1.8 \mathrm{~A}$ & $19.3 \pm 1.0 \mathrm{~A}$ & $21.5 \pm 2.6 \mathrm{~A}$ & $20.2 \pm 1.9 B$ & & & \\
\hline \multirow[t]{2}{*}{ Ether extract } & 7 & $18.5 \pm 1.8 \mathrm{Ab}$ & $22.1 \pm 2.1 \mathrm{Aa}$ & $21.0 \pm 1.1 \mathrm{Aab}$ & $23.5 \pm 3.1 \mathrm{Aa}$ & $<0.001$ & 0.0107 & 0.0255 \\
\hline & 26 & $71.2 \pm 1.7 \mathrm{Aa}$ & $69.8 \pm 1.9 \mathrm{Aab}$ & $67.6 \pm 2.9 A b$ & $68.1 \pm 1.9 \mathrm{Ab}$ & & & \\
\hline Crude protein & 7 & $71.2 \pm 1.7 \mathrm{Aa}$ & $66.2 \pm 1.4 \mathrm{Bb}$ & $67.4 \pm 1.4 \mathrm{Ab}$ & $65.9 \pm 1.7 \mathrm{Bb}$ & $<0.001$ & 0.0038 & 0.0499 \\
\hline
\end{tabular}

Means followed by different uppercase letters in the same column and different lowercase letters in the same row are significantly different by Tukey's test $(P<0.05)$. Results expressed as mean \pm SD $(n=8)$. Temp: storage temperature.

\section{Statistical analysis}

Data were submitted to analysis of variance using the $\mathrm{F}$ test $(P<0.05)$ and treatment means were compared by Tukey's test at $5 \%$ probability level $(P<0.05)$. Statistical analyses were performed using the software Statistix 10 (2016).

\section{RESULTS AND DISCUSSION}

Post mortem biochemical changes reduce body $\mathrm{pH}$ (Donaldson and Lamont, 2013). Immediately after slaughter, the average $\mathrm{pH}$ of the evaluated poultry carcasses was $6.1 \pm 0.2$, which was slightly reduced after $24 \mathrm{~h}$, independently of storage temperature (room temperature: $5.8 \pm 0.1$ and under refrigeration: $5.8 \pm 0.1)$. At 48 and $72 \mathrm{~h}$ of storage, the lowest $\mathrm{pH}(5.6 \pm 0.1)$ was obtained in the carcasses stored at room temperature for $48 \mathrm{~h}$, while the highest $\mathrm{pH}(6.0 \pm 0.1)$ in the carcasses refrigerated for $72 \mathrm{~h}$. Low $\mathrm{pH}$ values are associated with low water retention capacity, resulting in short shelf life and high cooking loss in fresh chicken meat (Allen et al., 1998; Khan et al., 2015).

The chemical composition ( $\mathrm{Ca}, \mathrm{P}$, ash, EE, and $\mathrm{CP}$ ) results of the evaluated PRM meals are presented in (Table 1). No significant influence of storage temperature and time or their interaction $(P>0.05)$ on $\mathrm{Ca}, \mathrm{P}$ or ash contents were observed. On the other hand, there were significant effects $(P<0.05)$ of storage temperature and time on $E E$, which ranged from $18.5 \pm 1.8$ to $23.5 \pm 3.1 \%$, and on $\mathrm{CP}$, with values ranging from $65.9 \pm 1.7$ to $71.2 \pm$ $1.7 \%$. In addition, a significant interaction $(P=0.0255)$ between the evaluated factors for $\mathrm{EE}$ content was detected: PRM of carcasses stored under refrigeration showed significantly higher EE content than those stored at room temperature for 72 hours.

Relative to $\mathrm{CP}$ content, the significant interaction $(P=0.0499)$ between the factors indicated that the PRM rendered from fresh carcasses had higher CP content
$(71.2 \pm 1.7 \%)$ than those stored for different times both at room temperature and under refrigeration $(65.9 \pm 1.7$ to $69.8 \pm 1.9 \%$ ). This result may be attributed to protein breakdown during spoilage, and the obtained values are close to those determined in commercial PRM by Ye et al. (2011).

The $\mathrm{Ca}, \mathrm{P}$ and ash contents of the PRMs produced in the present study, independently of storage temperature and time, are below those established by The Brazilian Compendium of Animal Feeds (CBAA, 2004), which establishes maximum $\mathrm{Ca}, \mathrm{P}$ and ash values of $8.50,2.50$ and $22 \%$, respectively, in rendered animal meals for their inclusion in feeds, suggesting that their inclusion does not compromise the mineral composition of broiler feeds. In addition, both EE and CP contents are higher than the minimum requirements (10 and $52 \%$, respectively), so that the evaluated PRMs can supply broilers' energy and protein requirements. Therefore, the chemical composition indicates that the produced PRMs are in line with commercial standards for poultry by-product meal. Another important aspect of rendered animal meal quality is the oxidation profile due to its high fat content, prone to oxidize, leading to the formation of free radicals (Bellaver, 2002). Table 2 presents the acidity index, peroxide index and TBARS analyzed in the PRMs as a consequence of storage temperatures and times. Significant interaction between temperature and storage time were observed for acidity $(P=0.0079)$ and peroxide $(P=0.0001)$ indices. Acidity index was significantly higher $(P<0.05)$ in the PRMs of carcasses stored at room temperature for 48 and $72 \mathrm{~h}(2.07$ and $2.15 \mathrm{mg} \mathrm{NaOH} / \mathrm{g}$, respectively) compared to those from fresh carcasses $(1.70 \mathrm{mg} \mathrm{NaOH} / \mathrm{g})$, whereas no differences $(P>0.05)$ were detected among PRMs from carcasses stored under refrigeration. Although no effect of temperature on peroxide index $(P>0.05)$ has been observed, significant interaction was detected between the factors $(P<0.0001)$ : at $72 \mathrm{~h}$ storage, PRM peroxide index was significantly lower when carcasses were stored at room temperature than under refrigeration (20.92 vs. 36.56 
Table 2. Oxidation profile of poultry rendered meal from whole broiler carcasses stored at different temperatures and for different times.

\begin{tabular}{|c|c|c|c|c|c|c|c|c|}
\hline \multirow[t]{2}{*}{ Parameter } & \multirow{2}{*}{$\begin{array}{l}\text { Temp. } \\
{ }^{\circ} \mathrm{C}\end{array}$} & \multicolumn{4}{|l|}{ Time $(\mathrm{h})$} & \multicolumn{3}{|l|}{$P$ value } \\
\hline & & 0 (zero) & 24 & 48 & 72 & Time & Temp. & Time*Temp. \\
\hline Acidity index & 26 & $1.70 \pm 0.24 b$ & $1.80 \pm 0.25 \mathrm{ab}$ & $2.07 \pm 0.23 a$ & $2.15 \pm 0.27 a$ & & & \\
\hline$(\mathrm{mg} \mathrm{NaOH} / \mathrm{g})$ & 7 & $1.70 \pm 0.24$ & $2.00 \pm 0.17$ & $1.83 \pm 018$ & $1.79 \pm 0.24$ & 0.0060 & 0.0971 & 0.0079 \\
\hline $\begin{array}{l}\text { Peroxide index } \\
\text { (meq/1000g) }\end{array}$ & $\begin{array}{l}26 \\
7\end{array}$ & $\begin{array}{l}22.61 \pm 4.69 b \\
22.61 \pm 4.69 b\end{array}$ & $\begin{array}{l}27.91 \pm 6.36 \mathrm{~b} \\
33.42 \pm 5.51 \mathrm{ab}\end{array}$ & $\begin{array}{l}43.04 \pm 10.80 a \\
32.93 \pm 7.46 a b\end{array}$ & $\begin{array}{l}20.92 \pm 4.93 \mathrm{Bb} \\
36.56 \pm 6.22 \mathrm{Aa}\end{array}$ & 0.0000 & 0.1265 & 0.0001 \\
\hline $\begin{array}{l}\text { TBARS } \\
(m g \text { MDA/kg) }\end{array}$ & $\begin{array}{l}26 \\
7\end{array}$ & $\begin{array}{l}24.31 \pm 6.51 \\
24.31 \pm 6.51\end{array}$ & $\begin{array}{l}26.52 \pm 3.81 \\
27.73 \pm 5.24\end{array}$ & $\begin{array}{l}26.68 \pm 1.90 \\
34.43 \pm 8.41\end{array}$ & $\begin{array}{l}26.69 \pm 6.02 \\
27.54 \pm 5.82\end{array}$ & 0.1122 & 0.1463 & 0.3526 \\
\hline
\end{tabular}

Means followed by different uppercase letters in the same column and different lowercase letters in the same row are significantly different by Tukey's test $(P<0.05)$. Results expresses as mean \pm SD $(n=8)$. TBARS: Thiobarbituric Acid Analysis. Temp.: Temperature.

Table 3. Biogenic amine content poultry rendered meal from whole broiler carcasses stored at different temperatures and for different times.

\begin{tabular}{|c|c|c|c|c|c|c|c|c|}
\hline \multirow{2}{*}{ Biogenic amine } & \multirow{2}{*}{$\begin{array}{l}\text { Temp. } \\
\text { Tem } \\
{ }^{\circ} \mathrm{C}\end{array}$} & \multicolumn{4}{|l|}{ Time (h) } & \multicolumn{3}{|l|}{$P$ value } \\
\hline & & 0 (zero) & 24 & 48 & 72 & Time & Temp. & Time ${ }^{\star}$ Temp. \\
\hline & 26 & $2.6 \pm 0.4 \mathrm{Ab}$ & $2.0 \pm 0.9 \mathrm{Ab}$ & $17.8 \pm 19.6 \mathrm{Aab}$ & $47.8 \pm 57.4 \mathrm{Aa}$ & & & \\
\hline Phenylethylamine & 7 & $2.6 \pm 0.4 \mathrm{Aa}$ & $3.5 \pm 2.0 \mathrm{Aa}$ & $8.0 \pm 4.1 \mathrm{Aa}$ & $2.3 \pm 0.5 \mathrm{Ba}$ & 0.0132 & 0.0153 & 0.0099 \\
\hline & 26 & $8.1 \pm 2.3 \mathrm{Ab}$ & $15.7 \pm 3.8 \mathrm{Ab}$ & $75.5 \pm 79.8 A a b$ & $145.2 \pm 138.8 \mathrm{Aa}$ & & & \\
\hline Putrescine & 7 & $8.1 \pm 2.3 \mathrm{Aa}$ & $12.3 \pm 2.7 \mathrm{Aa}$ & $14.9 \pm 4.1 \mathrm{Ba}$ & $14.4 \pm 3.4 \mathrm{Ba}$ & 0.0024 & 0.0011 & 0.0054 \\
\hline Cadaverine & $\begin{array}{l}26 \\
7\end{array}$ & $\begin{array}{l}58.5 \pm 30.9 \mathrm{Ab} \\
58.5 \pm 30.9 \mathrm{Ab}\end{array}$ & $\begin{array}{l}142.4 \pm 14.01 \mathrm{Ab} \\
126.0 \pm 37.8 \mathrm{Aa}\end{array}$ & $\begin{array}{l}197.0 \pm 94.0 \mathrm{Aab} \\
104.0 \pm 15.2 \mathrm{Ba}\end{array}$ & $\begin{array}{l}245.3 \pm 105.8 \mathrm{Aa} \\
116.3 \pm 33.0 \mathrm{Ba}\end{array}$ & $<0.001$ & $<0.001$ & $<0.001$ \\
\hline Histamine & $\begin{array}{l}26 \\
7\end{array}$ & $\begin{array}{l}4.0 \pm 0.8 \mathrm{Ab} \\
4.0 \pm 0.8 \mathrm{Aa}\end{array}$ & $\begin{array}{l}3.8 \pm 0.7 \mathrm{Ab} \\
3.7 \pm 0.6 \mathrm{Aa}\end{array}$ & $\begin{array}{l}5.9 \pm 2.0 \mathrm{Ab} \\
3.8 \pm 0.5 \mathrm{Aa}\end{array}$ & $\begin{array}{l}11.0 \pm 4.8 \mathrm{Aa} \\
3.9 \pm 0.5 \mathrm{Ba}\end{array}$ & $<0.001$ & $<0.001$ & $<0.001$ \\
\hline Tyramine & $\begin{array}{l}26 \\
7\end{array}$ & $\begin{array}{l}12.5 \pm 11.5 \mathrm{Ab} \\
12.5 \pm 11.5 \mathrm{Ac}\end{array}$ & $\begin{array}{l}40.8 \pm 8.3 \mathrm{Ab} \\
47.7 \pm 16.0 \mathrm{Ab}\end{array}$ & $\begin{array}{l}114.7 \pm 41.2 \mathrm{Aa} \\
91.6 \pm 19.0 \mathrm{Aa}\end{array}$ & $\begin{array}{l}109.5 \pm 27.7 \mathrm{Aa} \\
48.2 \pm 15.1 \mathrm{Bb}\end{array}$ & $<0.001$ & $<0.001$ & $<0.001$ \\
\hline Spermidine & $\begin{array}{l}26 \\
7\end{array}$ & $\begin{array}{l}35.8 \pm 6.4 \mathrm{Aa} \\
35.8 \pm 6.4 \mathrm{Aa}\end{array}$ & $\begin{array}{l}33.3 \pm 6.0 \mathrm{Aa} \\
34.8 \pm 6.9 \mathrm{Aa}\end{array}$ & $\begin{array}{l}28.7 \pm 4.7 \mathrm{Aa} \\
33.1 \pm 3.7 \mathrm{Aa}\end{array}$ & $\begin{array}{l}23.1 \pm 8.0 \mathrm{Ba} \\
35.1 \pm 5.6 \mathrm{Aa}\end{array}$ & 0.0144 & 0.0049 & 0.0354 \\
\hline Spermine & $\begin{array}{l}26 \\
7\end{array}$ & $\begin{array}{l}64.2 \pm 11.8 \mathrm{Aa} \\
64.2 \pm 11.8 \mathrm{Aa}\end{array}$ & $\begin{array}{l}53.5 \pm 10.3 \mathrm{Aa} \\
56.1 \pm 14.0 \mathrm{Aa}\end{array}$ & $\begin{array}{l}39.4 \pm 8.6 \mathrm{Bab} \\
51.7 \pm 8.8 \mathrm{Aa}\end{array}$ & $\begin{array}{l}29.5 \pm 17.4 \mathrm{Bb} \\
59.0 \pm 11.7 \mathrm{Aa}\end{array}$ & $<0.001$ & $<0.001$ & 0.0044 \\
\hline
\end{tabular}

Means followed by different uppercase letters in the same column and different lowercase letters in the same row are significantly different by Tukey's test $(P<0.05)$. Results expressed as mean \pm SD $(n=8)$. Temp: storage temperature.

meq/1000 g, respectively). The TBA values were not influenced $(P<0.05)$ by the evaluated factors.

Rendered animal meals are rich in fat, explaining the high peroxide and acidity indices observed (Jayathilakan et al., 2012). However, the acidity indices obtained in this study were around $2 \mathrm{mg} \mathrm{NaOH} / \mathrm{g}$, the recommended value for animal meals (Bellaver and Zanotto, 2004). Less than $6 \mathrm{mg} \mathrm{NaOH} / \mathrm{g}$ indicates absence of hydrolytic rancidity (ANFAR/SINDIRAÇÕES, 1998). On the other hand, the peroxide index of all PRMs evaluated in this study was higher than $20 \mathrm{meq} / 1000 \mathrm{~g}$, above the maximum standard value of $10 \mathrm{meq} / 1000 \mathrm{~g}$ allowed for PRMs (ANFAR/SINDIRAÇÕES, 1998).

The oxidation process involves self-catalytic reactions that generate free radicals at increasing rates. The factors that may influence the formation of free radicals include, in particular, high temperature, radiation, enzymes, light and the presence of metal ions (Rutz and Lima, 1994). In this context, the observed general increase in oxidation rates as a function of storage time, independently of storage temperature, may be partially explained by the increased enzymatic fat breakdown related to microbial proliferation, oxygen exposure and higher levels of free fatty acids derived from triacylglycerol hydrolysis (Cecchi, 2003; Instituto Adolfo Lutz, 2008), among other factors. It is also important to consider that intentionally no antioxidants were added to the trial at any moment.

In the present study, the group of BA analyzed in feeds PRM as spoilage markers were phenylethylamine, putrescine, cadaverine, histamine, tyramine, spermidine and spermine. In Table 3, the levels of those BA determined in the evaluated PRMs are presented as a function of carcass storage temperature and time. Biogenic amine levels were significantly influenced $(P<0.05)$ by carcass storage temperature and time before rendering; however, a wide variation in the BA profile of the PRMs was detected. Figure 1 clearly shows the influence of storage temperature on the biogenic amine profiles along storage times. In PRMs generated from carcasses stored at room temperature, histamine, phenylethylamine, putrescine, cadaverine and tyramine levels increased along storage time, while spermine and spermidine levels decreased. On the other hand, when carcasses were stored under refrigeration, the levels of putrescine, cadaverine and phenylethylamine of the rendered PRMs increased along storage time. The timedependent reduction of spermine and spermidine levels 


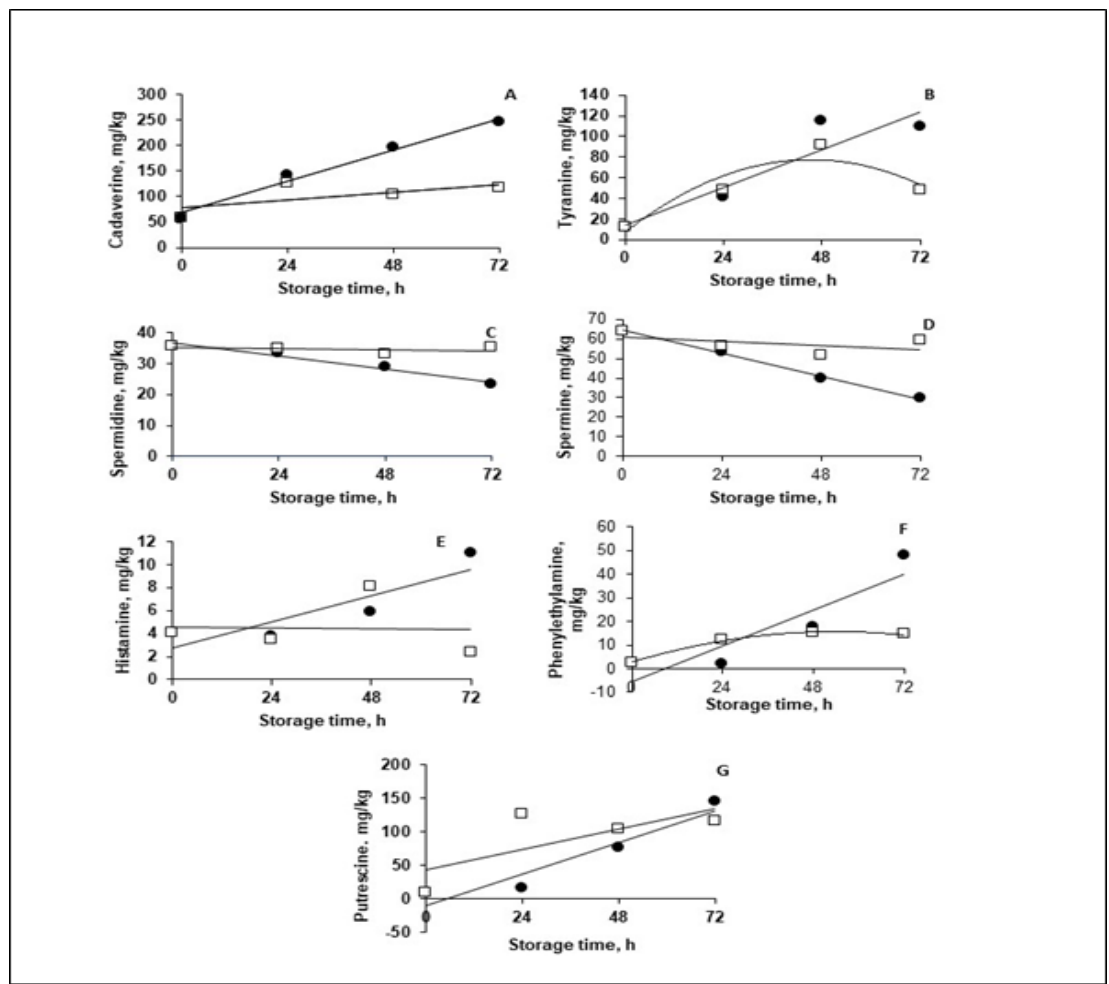

Figure 1. Biogenic amine contents of poultry rendered meal from whole broiler carcasses stored at different temperatures and for different times $\cdot=$ room temperature $\left(26^{\circ} \mathrm{C}\right)$; $\square=$ under refrigeration $\left(7^{\circ} \mathrm{C}\right)$.

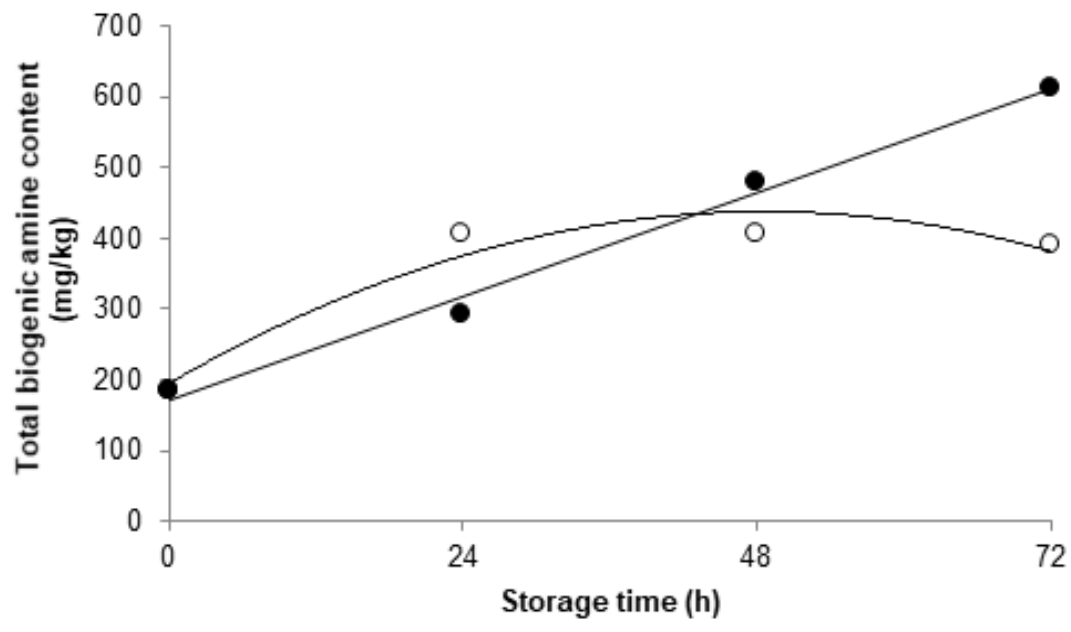

Figure 2. Total biogenic amine content of poultry rendered meal from whole broiler carcasses stored at different temperatures and for different times $\cdot=$ room temperature $\left(26^{\circ} \mathrm{C}\right) ; \mathrm{o}=$ under refrigeration $\left(7^{\circ} \mathrm{C}\right)$.

was also observed by Tamim and Doerr (2003) in PRMs rendered from poultry carcasses.

Several biochemical pathways are involved in the production of BA from different amino acids derived from protein hydrolysis. In addition, it is known that the production of $\mathrm{BA}$ is influenced by several factors such as temperature, $\mathrm{pH}$, microbiota, among others. These factors partially explain the different BA profiles observed in this study. Additionally, for better perception, total BA content was calculated as a function of carcass storage temperature and time, as shown in Figure 2. Total BA content of PRMs rendered from fresh carcasses was $185.76 \mathrm{mg} / \mathrm{kg}$. In PRMs from carcasses stored under refrigeration, total BA content increased to $406.37 \mathrm{mg} / \mathrm{kg}$ 
at $24 \mathrm{~h}$ of storage, and remained virtually constant up to $72 \mathrm{~h}(391.76 \mathrm{mg} / \mathrm{kg})$, whereas when carcasses were stored at room temperature, total BA content increased along storage time, with the highest value (611.46 $\mathrm{mg} / \mathrm{kg}$ ) obtained at $72 \mathrm{~h}$ of storage.

Several countries have established maximum allowed limits for biogenic amine levels in foods (Gomes et al., 2014). In Brazil, there is only one regulation (Ministerial Ordinance 185/1997), which establishes the maximum limit of $100 \mathrm{mg}$ histamine/kg in fish (MAPA, 1997). In the absence of specific legislation for BA content for animal products used as feedstuffs, individual companies of the animal industry have researched reference values for several physicochemical parameters in order to ensure animal byproduct quality, and, in particular, BA content as high levels of these compounds may trigger adverse events both in farm animals and humans. Therefore, research in that field is essential to allow the establishment of specific legislation and to aid decisionmaking by regulatory agencies.

Normative Instruction 34/2008 of the Brazilian Ministry of Agriculture (MAPA) prohibits rendering of on-farm animal mortality carcasses for the production of animal meals to be used as feedstuffs. Nevertheless, the present study demonstrated that the nutritional composition of PRMs originated from whole broiler carcasses have quality enough to possibly be used as feedstuff. Although PRMs from carcasses stored under refrigeration presented better oxidation and BA indices compared with those stored at room temperature, in both cases these parameters deteriorated as a function of storage time, and therefore, it is recommended that carcasses should be rendered immediately after death. Besides, further studies are needed to establish the safety of these byproducts as feedstuffs in animal production.

\section{ACKNOWLEDGEMENTS}

The sincerely thank the Brazilian Agricultural Research Agency (Embrapa Swine and Poultry) and the Federal University of Pelotas (UFPEL) for supporting this study. Also, The Coordination for the Improvement of Higher Education Personnel (CAPES) for granting the scholarship for the first author and The National Council for Scientific and Technological Development (CNPq) for granting a research sponsorship for the last author.

\section{REFERENCES}

Allen CD, Fletcher DL, Northcutt JK, Russell SM (1998). The relationship of broiler breast color to meat quality and shelf-life. Poult. Sci. 77(2): 361-366. https://doi.org/10.1093/ps/77.2.361

ABPA (2020). Brazilian Animal Protein Association, Annual Report, Brazil. http://abpa-br.com.br/ (Accessed on June 18, 2020).

National Association of Feed Manufacturers / National Union of Animal Feed Industries (ANFAR / SINDIRAÇÕES). 1998. Standardization of raw materials for animal feed. Sao Paulo-SP; pp. 1-51.

Association of Official Analytical Chemists (AOAC) (1998). Official methods of analysis of the Association of Official Analytical Chemists. 16th Edn. AOAC International. Arlington, TX.

Bellaver $C$ (2002). Use of animal residues in broiler feed. Proceeding of the Brazil Sul de Avicultura Symposium 2002. Chapecó, SC; P. 6.

Bellaver C, Zanotto DL (2004). Quality parameters in animal fats and protein by-products. Proceeding of the APINCO Poultry Science and Technology Conference 2004. Santos, SP; P. 21.

Bover-Cid S, Miguelez-Arrizado MJ, Moratalla LLL, Carou MCV (2006). Freezing of meat raw materials affects tyramine and diamine accumulation in spontaneously fermented sausages. Meat Sci., 72(1): 62-68. https://doi.org/10.1016/j.meatsci.2005.06.003

BRAZIL. Normative Instruction No. 15 of October 29, 2003. Department of Inspection of Products of Animal Origin (DIPOA), Secretariat of Agricultural Defense (SDA), Ministry of Agriculture, Livestock and Supply (MAPA), Brasília, 2003.

BRAZIL. Ministry of Agriculture, Livestock and Supply (MAPA). MAPA Normative Instruction No. 34, of May 28, 2008. Approve the Technical Regulation for Hygienic-Sanitary and Technological Inspection of Animal Waste Processing and the Animal Waste Transport Document Model.

BRAZIL. Ministry of Agriculture, Livestock and Supply (MAPA). Ordinance No. 185, of May 13, 1997 of the Regulation for Industrial and Sanitary Inspection of Products of Animal Origin. Technical Regulation of Fresh Fish Identity and Quality (Whole and Gutted).

Cardozo M, Lima KS, Franca TC, Lima, ALS (2013). Biogenic amines: a public health problem. Ver. Virtual Quim. 5 (2): 149-168. DOI: 10.5935 / 1984-6835.20130018

Cecchi H M (2003). Theoretical and practical foundations in food analysis. 2nd Edn. Publisher UNICAMP. Campinas, sp.

Brazilian Compendium of Animal Feeding (CBAA). 2004. São Paulo: Sindamentos / Anfal. Campinas CBNA / SDR / MA.

Donaldson AE, Lamont IL (2013). Biochemistry changes that occur after death: potential markers for determining post-mortem interval. Plos one, 8(11): e82011. https://doi.org/10.1371/journal.pone.0082011

Gerber P, Opio C, Steinfeld H (2007). Poultry production and the environment $-a$ review. Poultry in the $21^{\text {st }}$ Century - Avian Influenza and Beyond. Bangkok, Thailand.

Gomes MB, Pires BAD, Fracalanzza SAP, Marin VA (2014). The risk of biogenic amines in food. Ciênc. Saúde Colet.,19: 1123-1134. https://doi.org/10.1590/1413-81232014194.18672012

Hamilton CR, Kirstein D, Breitmeyer RE. (2006). The rendering industry's biosecurity contribution to public and animal health. In Meeker DL. Essential Rendering. Arlington, TX: National Renderers Association, pp. 71-94

Instituto Adolfo Lutz. Physico-chemical methods for food analysis. 4th ed. Sao Paulo-SP; 2008.

Jayathilakan K, Sultana K, Radhakrishna K, Bawa AS (2012). Utilization of byproducts and waste materials from meat, poultry and fish processing industries: a review. J. Food Sci. Technol. 49(3): 278293. https://doi.org/10.1007/s13197-011-0290-7

Jorge Neto $G$ (1994). Nutritional quality of poultry grease product. In: Slaughter and processing of chickens; Campinas, SP: FACTA; 1994. p. 115.

Khan A, Allen K, Wang X (2015). Effect of Type I and Type II antioxidants on oxidative stability, microbial growth, $\mathrm{pH}$, and color in raw poultry meat. Food Nutr Sci, 6(16): 1541. DOI: 10.4236/fns.2015.616159

Krabbe EL, Wilbert CA (2016). The liabilities of animal protein production chains - dead animals. Industrial Poultry, 1251: 24-31.

Latorre-Moratalla ML, Bover-Cid S, Talon R, Garriga M, Zanardi E, lanieri A, Fraqueza MJ, Elias M, Drosinos EH, Vidal-Carou MC (2010). Strategies to reduce biogenic amine accumulation in traditional sausage manufacturing. LWT-Food Sci. Technol. 43(1): 20-25. https://doi.org/10.1016/j.Iwt.2009.06.018

Lázaro CA, Conte-Júnior CA, Canto AC, Monteiro MLG, Costa-Lima B, da Cruz AG, Mársico ET, Franco RM. (2015). Biogenic amines as bacterial quality indicators in different poultry meat species. LWTFood Sci. Technol. 60(1): 15-21. https://doi.org/10.1016/j.lwt.2014.09.025

Leiva A, Granados-Chinchilla F, Redondo-Solano M, Arrieta-González M, Pineda-Salazar E, Molina A (2018). Characterization of the animal by-product meal industry in Costa Rica: Manufacturing practices 
2169.

Rutz F, Lima, G. L. M. M (1994). Use of antioxidants in feed and byproducts. Proceeding of the APINCO Poultry Science and Technology Conference, 1994. Campinas, SP; 1994. p. 73.

Shantha NC, Decker EA (1994). Rapid, sensitive, iron-based spectrophotometric methods for determination of peroxide values of food lipids. J. AOAC Int. 77(2), 421-424. https://doi.org/10.1093/jaoac/77.2.421

Smělá D, Pechova P, Komprda T, Klejdus B, Kuban V (2003). Liquid Chromatographic Determination of Biogenic Amines in a Meat Product during Fermentation and Long-term Storage. Czech J. Food Sci. 21: 67-175.

Stadnik J, Dolatowski ZJ (2010). Biogenic amines in meat and fermented meat products. ACTA Sci. Pol. Technol. Aliment. 9: 251263.
STATISTIX 10. Analytical Software PO Box 12185, Tallahassee, FL 323172016.

Tamim NM, Doerr JA. (2003). Effect of putrefaction of poultry carcasses prior to rendering on biogenic amine production. J. Appl. Poultry Res. 12(4): 456-460. https://doi.org/10.1093/japr/12.4.456

Ye JD, Wang K, Li FD, Sun YZ, Liu XH (2011). Incorporation of a mixture of meat and bone meal, poultry by-product meal, blood meal and corn gluten meal as a replacement for fish meal in practical diets of Pacific white shrimp Litopenaeus vannamei at two dietary protein levels. Aquacult. Nutr. 17(2): e337-e347. https://doi.org/10.1111/j.1365-2095.2010.00768. 